\title{
METODE PEMBELAJARAN KOPERATIF UNTUK KESIAPAN BELAJAR MATEMATIKA SISWA MTS
}

\author{
Nurrul Khotimah, Adi Heryadi \\ Sekolah Tinggi Ilmu Psikologi Yogyakarta, Universitas Jenderal Ahmad Yani Yogyakarta \\ E-mail: adiheryadi16@gmail.com
}

\begin{abstract}
This study aimed to prove cooperative learning in improving mathematics learning readiness of Islamic junior high school (MTs) students. This research was an experimental study with 50 partisipants that devided randomly in two groups, experiment and control. The design of the experiment was a pretest-posttest control group. The experiment was engeged in cooperative learning in mathematics subject and the control group only learned mathematic subject in traditional methods. The instrument was students' readiness questionaire with reliability coefficient of 0.913. The results showed that cooperative learning methods improved the mathematics learning readiness of Islamic Junior High School students. Mathematics learning readiness is important to improved before the students learn mathematics in class.
\end{abstract}

Keywords: Cooperative Learning Method, Learning Readiness, Experiment Research

\begin{abstract}
Abstrak
Penelitian ini bertujuan untuk membuktikan secara empiris bahwa metode pembelajaran kooperatif efektif untuk meningkatkan kesiapan belajar matematika siswa MTs. Penelitian ini merupakan penelitian eksperimen dengan kelompok eksperimen berjumlah 25 orang siswa dan kelompok kontrol berjumlah 25 siswa juga yang dipilih secara acak. Desain eksperimen yang digunakan adalah pre-test-postes control group design. Setelah itu kelompok eksperimen memperoleh perlakuan berupa belajar matematika dengan metode pembelajaran kooperatif sementara kelompok kontrol hanya belajar matematika dengan metode tradisional selanjutnya diukur kembali melalui postes. Alat ukur yang digunakan dalam pengumpulan data berupa skala kesiapan belajar siswa yang dibuat oleh peneliti dengan nilai koefisien reliabilitas sebesar 0,913 . Hasil penelitian menunjukan pembelajaran kooperatif meningkatkan kesiapan belajar matematika para siswa MTs. Penting mengetahui kesiapan siswa untuk memahami lebih baik kondisi psikologis siswa sebelum belajar.
\end{abstract}

Kata Kunci: Metode Pembelajaran Kooperatif, Kesiapan Belajar, Penelitian Eksperimen

\section{PENDAHULUAN}

Ada banyak manfaat pelajaran matematika yaitu (a) bisa memudahkan memahami pelajaran lain, seperti kimia, fisika, ekonomi dan pelajaran yang menyangkut matematika, (b) bisa membuat kita lebih teliti, (c) menjadikan kita lebih sabar, (d) memudahkan kita 
mencari pekerjaan, dan (e) melatih kemampuan otak kita. Banyak manfaat yang didapat dalam mempelajari matematika. Karena matematika adalah ilmu dasar dari segala ilmu yang berhubungan dengan bilangan (Suwangsih dkk., 2018). Sekalipun diajarkan sejak dini, masih banyak siswa yang mengalami kesusahan dalam mata pelajaran matematika pada tingkat selanjutnya. Permasalahan ini berdampak kualitas kemampuan matematika siswa Indonesia pada Survey Programme For International Student Assesment (PISA) tahun 2018 hanya berada pada peringkat dunia ke 73 dari 77 negara (Schleicher, 2018).

Hasil belajar matematika siswa yang buruk karena kurangnya kesiapan dalam belajar (Fitriana, 2013; Saputri \& Budiyono, 2016; Nurrohmah, 2018). Kesiapan belajar adalah kondisi yang mendahului aktivitas itu sendiri. Siswa yang mempunyai kesiapan belajar yang baik tentunya dapat mengikuti pembelajaran dengan aktif dan mudah menyerap pelajaran sehingga mampu berkonsentrasi terhadap apa yang disampaikan guru (Nasution, 2017). Apabila siswa memiliki kesiapan yang matang, maka siswa akan memperoleh kemudahan dalam memperdalam materi pelejaran dan konsentrasi dalam proses pembelajaran (Mulyani, 2013). Diperlukan metode pembelajaran yang bisa mempersiapkan kesiapan belajar. Salah satu metode pembelajaran itu adalah metode pembelajaran kooperatif.

Metode pembelajaran kooperatif di Indonesia salah satunya dikembangkan oleh Indiyani dan Listiara (2006). Teknik pembelajaran kooperatif ini memberikan kesempatan kepada siswa untuk saling membagikan ide tentang materi pembelajaran yang sebelumnya sudah diberika guru dan mendiskusikan materi pembelajaran yang akan diberikan guru. Manfaat metode pembelajaran kooperatif menurut Johnson (Fajri dkk. (2016), pembelajaran kooperatif juga menghasilkan peningkatan kemampuan akademik, meningkatkan kemampuan berpikir kritis, membentuk hubungan persahabatan, menimba berbagai informasi, belajar menggunakan sopan santun, meningkatkan motivasi siswa, memperbaiki sikap terhadap sekolah dan belajar mengurangi tingkah laku yang kurang baik, serta membantu siswa dalam menghargai pokok pikiran orang lain.

Model pembelajaran kooperatif ini memberi kesempatan kepada siswa untuk bekerja sendiri dan bekerja sama dengan orang lain. Keunggulan lain dari pembelajaran kooperatif ini adalah optimalisasi partisipasi siswa. Dalam metode pembelajaran ini dimana siswa saling bertukar pendapat maupun pertanyaan mengenai materi pembelajaran yang sudah maupun yang akan di pealjari di dalam kelas (Indiyani \& Listiara, 2006).

Diharapkan dengan teknik tersebut dapat meningkatkan kesiapan belajar matematika siswa untuk dapat mengikuti proses pembelajaran dengan baik. Seperti halnya yang telah dilakukan oleh peneliti sebelumnya bahwa metode pembelajaran kooperatif mampu menurunkan tingkat kecemasan siswa. Dari uraian diatas, penelitian ini ingin menguji apakah metode pembelajaran kooperatif berpengaruh terhadap kesiapan belajar matematika siswa? 
INPUT

PROSES

OUTPUT

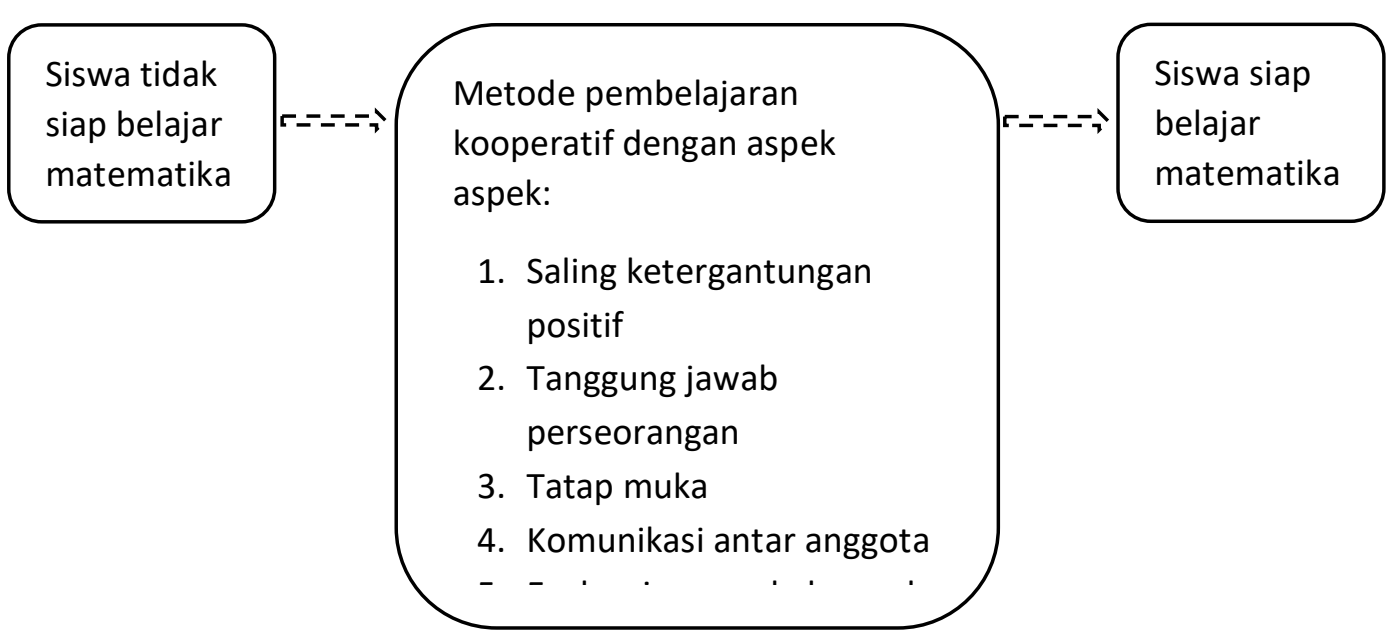

Gambar 1

Proses Metode Pembelajaran Kooperatif

\section{METODE}

\section{Desain Penelitian}

Penelitian ini merupakan penelitian kuantitatif pendekatan eksperimental yang menggunakan rancangan eksperimen pre-tes-postes control group design. Subjek penelitian terbagi menjadi dua kelompok, yaitu kelompok eksperimen dan kelompok kontrol. Kelompok eksperimen diberi metode Pembelajaran Kooperatif sedangkan kelompok kontrol mendapatkan pembelajaran tradisonal dan kedua kelompok mendapatkan pretes dan postes kesiapan belajar.

Tabel 1

Desain eksperimen pola Randomized Control-Group Posttest Design

\begin{tabular}{cccc} 
Grup & Pretes & X & Postes \\
\hline Eksperimen & $\mathrm{O}_{1}$ & Pembelajaran Kooperatif & $\mathrm{O}_{2}$ \\
\hline Kontrol & $\mathrm{O}_{3}$ & - & $\mathrm{O}_{4}$ \\
\hline
\end{tabular}

Model pembelajaran kooperatif menggunakan desain pembelajaran kelompok diskusi dengan melibatkan beberapa kelompok yang setiap kelompok terdiri dari 3 sampai 5 siswa. Metode pembelajaran kooperatif ini tidak hanya sekedar pembelajaran kelompok 
biasa karena harus ada lima aspek didalamnya (Lie, 1999): ketergantungan positif, tanggung jawab perseorangan, tatap muka, komunikasi antar anggota dan evaluasi proses kelompok. Sebuah modul disusun untuk menerapkan lima aspek metode pembelajaran kooperatif untuk digunakan sebagai pedoman pelatihan penerapan metode pembelajaran kooperatif.

Kesiapan belajar siswa mencakup aspek-aspek: perhatian dalam belajar, motivasi belajar dan perkembangan kesiapan. Kesiapan belajar diartikan sebagai kondisi dimana siswa siap dalam menerima stimulus berupa informasi yang diberikan oleh guru ketika proses pembelajaran berlangsung dan siswa mampu merespon stimulus tersebut yang diukur dengan skala kesiapan belajar yang terdiri dari tiga aspek kesiapan belajar menurut teori Nasution (2017) yakni perhatian, motivasi, dan perkembangan kesiapan.

\section{Partisipan}

Partisipan penelitian terdiri 50 siswa Madrasah Tsanawiyah (kelas 7 -9) yang terbagi menjadi dua kelompok yang masing-masing terdiri dari 25 siswa yaitu kelompok eksperimen dan kontrol yang dilakukan secara random. Pretes kesiapan belajar matematika dilakukan kepada kelompok eksperimen dan kelompok kontrol dengan waktu yang tidak bersamaan. Pretes dilakukan dengan kuesioner kesiapan belajar yang sudah melalui uji coba skala sebelumnya dan sudah teruji.

\section{Metode Pembelajaran Kooperatif}

Metode pembelajaran kooperatif dilaksanakan dalam 5 sesi yang diawali dengan sesi tatap muka: sesi ini diawali dengan penyampaian materi dan juga pengenalan metode pembelajaran yang akan dijalankan sehingga tujuan sesi ini tercapai: 1) siswa dapat memahami metode pembelajaran kooperatif, 2) siswa dapat berinteraksi dengan baik terhadap kelompok sehingga proses diskusi berjalan lancar dan 3) siswa mampu memahami dengan jelas prosedur maupun materi pembelajaran matematika.

Sesi komunikasi: tujuannya 1) membentuk siswa aktif dalam kelompok melalui komunikasi, dan 2) menjadikan siswa aktif dalam proses pembelajaran bahkan termasuk siswa yang tidak memiliki keahlian atau kemampuan berkomunikasi. Keberhasilan kelompok bergantung pada kesediaan anggotanya untuk saling mendengarkan dan kemampuan mereka untuk mengutarakan pendapat mereka dalam kelompok.

Sesi tanggung jawab perseorangan: bertujuan 1) untuk menumbuhkan rasa tanggung jawab terhadap diri sendiri sehingga timbul kesadaran diri akan pentingnya penguasaan materi yang diberikan guru, 2) membantu siswa lain ketika mengalami kesusahan dalam memahami materi pembelajaran, membantu meringankan kewajiban guru dalam memberikan informasi mengenai materi pembelajaran yang telah di berikan.

Sesi ketergantungan positif: bertujuan menumbuhkan rasa ketergantungan positif antar anggota dalam kelompok, meringankan guru dalam menjelaskan materi pada setiap 
siswa. Ketergantungan positif disini diasumsikan dalam bentuk kerja sama yang terus menerus dimiliki seluruh anggota kelompok untuk menanamkan rasa tanggung jawab bahwa mereka berhubungan dengan satu sama lainya dalam satu cara dimana seseorang tidak dapat mengerjakanya kecuali dengan bekerja bersama dengan orang lain dalam kelompok yang telah dibangun.

Sesi evaluasi proses kelompok: bertujuan untuk mengetahui tingkat keaktifan siswa dalam kelompok, guru dapat melihat tingkat pemahaman siswa pada materi studi matematika yang telah guru berikan. Setiap melakukan kegiatan kelompok sangat dibutuhkan untuk mengoreksi kekurangan maupun kelebihan, hambatan maupun kelancaran dalam proses diskusi pada masing-masing kelompok. Selain itu dengan adanya evaluasi, guru dengan mudah melihat celah yang perlu diperbaiki maupun ditingkatkan untuk membantu kelompok berkembang pada proses pembelajaran selanjutnya yang akan dilakukan. Setiap kelompok diberikan kesempatan untuk maju ke depan kelas menjelaskan hasil diskusi kelompoknya yang dipilih secara acak oleh peneliti dan juga diberikan lembar evaluasi peneliti yang diberikan kepada ketua kelompok.

\section{Pengukuran postes}

Postes dilakukan pada kelompok kontrol dan kelompok ekperimen namun dengan waktu yang berbeda. Kelompok kontrol mengisi postes setelah tiga hari namun tanpa perlakuan sedangkan kelompok eksperimen melakukan postes setelah pemberian perlakuan selesai dengan jarak waktu yang sama dari pretes.

\section{Instrumen}

Skala kesiapan belajar. Skala ini berbentuk kuesioner yang berupa pernyataan-pernyataan yang diberikan kepada responden untuk dijawab. Pada penelitian ini model skala digunakan untuk mengumpulkan data mengenai kesiapan belajar siswa. Adapun prosedur pemberian skor untuk menjawab angket yang diberikan kepada responden yaitu untuk soal yang merupakan pernyataan positif, siswa memberikan pernyataan sangat setuju diberi skor 4, setuju diberi skor 3, tidak setuju diberi sekor 2, dan sangat tidak setuju diberi skor 1 . Sedangkan untuk butir soal yang merupakan pernyataan negatif, siswa yang memberikan pernyataan sangat setuju diberi skor 1 , setuju diberi skor 2, tidak setuju diberi skor 3, dan sangat tidak setuju diberi skor 4. Skala kesiapan belajar dalam penelitian ini memiliki nilai koefisien alpha 0,913 .

\section{HASIL}

Peneliti melakukan kategorisasi subjek penelitian berdasarkan skor kesiapan belajar matematika untuk melihat subjek penelitian termasuk dalam kategori yang mempunyai 
kesiapan rendah, sedang, atau tinggi. Kategori atau penggolongan dapat dilihat pada tabel 2.

Tabel 2

Distribusi Kesiapan Belajar Matematika

\begin{tabular}{ccccc}
\hline Kategori & $\begin{array}{c}\text { Kelompok } \\
\text { Eksperimen }\end{array}$ & $\begin{array}{c}\text { Kelompok } \\
\text { Kontrol }\end{array}$ & Frekuensi & $\begin{array}{c}\text { Persentase } \\
(\boldsymbol{\%})\end{array}$ \\
\hline Rendah & 0 & 0 & 0 & $0 \%$ \\
\hline Sedang & 18 & 8 & 26 & $52 \%$ \\
\hline Tinggi & 7 & 17 & 24 & $48 \%$ \\
\hline & 25 & 25 & 50 & $100 \%$
\end{tabular}

Tabel 3

Pretes Kesiapan Belajar

\begin{tabular}{ccccccccc}
\hline Kelompok & N & $\begin{array}{c}\text { Rata- } \\
\text { Rata }\end{array}$ & SD & SE & $\begin{array}{c}\text { Perbedaan Rata- } \\
\text { Rata }\end{array}$ & t & df & p \\
\hline Eksperimen & 25 & 82.680 & 7.978 & 1.596 & 8,240 & - & 48.000 & $<.001$ \\
\hline Kontrol & 25 & 90.920 & 8.200 & 1.640 & & & 3.601 & \\
\hline
\end{tabular}

Tabel 4

Uji T Pretes dan Postes Kesiapan Belajar Kelompok Eksperimen

\begin{tabular}{ccccccccc}
\hline Kelompok & N & Rata-Rata & SD & SE & Perbedaan Rata-Rata & t & df & p \\
\hline Pretes & 25 & 82,680 & 7,978 & 1.596 & $-14,360$ & $-13,222$ & 24 & $<.001$ \\
\hline Postes & 25 & 97,040 & 8,299 & 1.660 & & & & \\
\hline
\end{tabular}

Tabel 5

Uji T Pretes dan Postes Kesiapan Belajar Kelompok Kontrol

\begin{tabular}{ccccccccc}
\hline Kelompok & N & Rata-Rata & SD & SE & Perbedaan Rata-Rata & t & df & p \\
\hline Pretes & 25 & 90,920 & 8,200 & 1.640 & 4,280 & 6,254 & 24 & $<.001$ \\
\hline Postes & 25 & 86,640 & 6,422 & 1.284 & & & &
\end{tabular}

Tabel 6

Postes Kesiapan Belajar

\begin{tabular}{ccccccccc}
\hline Kelompok & N & Rata-Rata & SD & SE & Perbedaan Rata-Rata & t & df & p \\
\hline Eksperimen & 25 & 97.040 & 8.299 & 1.660 & 10,400 & 4.955 & 48.000 & $<.001$ \\
\hline Kontrol & 25 & 86.640 & 6.422 & 1.284 & & & & \\
\hline
\end{tabular}

Secara deskriptif, rata-rata pretes kelompok eksperimen lebih kecil yaitu 82,680 dibanding rata-rata pretes kelompok kontrol yaitu 90,920, dan menghasilkan $t=-3,601$ 
dan nilai signfikan $<0,05$ yang artinya bahwa skor pretes rata-rata kelompok eksperimen lebih rendah dibandingkan kelompok kontrol.

Dari uji t skor rata-rata pretes dan postes kelompok eksperimen menghasilkan nilai sebesar $-13,222$ (p. 0,000), dengan selisih rata-rata pretes dan postes adalah 14,360, sehingga dapat dinyatakan bahwa kelompok eskperimen mengalami peningkatan skor kesiapan belajar matematika dari sebelum dan sesudah pembelajaran koperatif. Dari uji t pada kelompok kontrol, rata-rata pretes dan postes mengalami penurunan yang signifikan sebesar 4,280.

Hipotesis yang diajukan adalah ada pengaruh yang signifikan antara penereapan metode pembelajaran kooperatif terhadap peningkatan kesiapan belajar matematika pada siswa. Hasil $t$ test dalam penelitian ini menunjukkan nilai $\mathrm{F}$ 6,719 dengan nilai $\mathrm{P} 0,565$ taraf signifikansi $\mathrm{P}>0,05$, maka hipotesis diterima. Hal tersebut menunjukkan bahwa ada pengaruh yang signifikan antara pemberian pelatihan penerapan metode pembelajaran kooperatif terhadap kenaikan kesiapan belajar matematika pada siswa. Dari uji t yang maka diperoleh perubahan perbedaan skor rata-rata dimana dapat dilihat bahwa rata-rata postes kelompok eksperimen sebesar 97,04 sedangkan kelompok kontrol sebesar 86,64 maka didapat rata-rata perbedaan sebesar 10,400 dengan $\mathrm{t}=4,955$.

Hasil yang diperoleh dari pengujian hipotesis menunjukkan bahwa ada pengaruh metode pembelajaran kooperatif untuk meningkatkan kesiapan belajar matematika pada siswa MTs. Dari data-data penelitian yang telah dianalisis menggunakan uji t-test, menunjukkan adanya peningkatan skor kesiapan belajar matematika pada siswa yang signifikan pada kelompok eksperimen antara sebelum dan sesudah perlakuan dengan perbedaan rata-rata sebesar 14,360 dengan $t=-6,237$. Sedangkan kelompok kontrol tidak mengalami peningkatan skor kesiapan belajar matematika melainkan terjadi penurunan rata-rata sebesar 44,280 dengan $\mathrm{t}=2,055$.

Skor pretes kesiapan belajar matematika siswa pada kelompok eksperimen dan kelompok kontrol diuji dengan menggunakan teknik statistik independent sample t-test. Dari hasil analisis tersebut menunjukkan bahwa ada perbedaan rata-rata yang signifikan dimana rata-rata pretes kelompok eksperimen sebesar 86,64 sedangkan pretes kelompok kontrol sebesar 97,04 sehingga perbedaan skor rata-rata pretes kedua kelompok tersebut sebesar 8,240. Hasil tersebut menunjukkan bahwa kesiapan belajar matematika siswa pada kelompok eksperimen lebih rendah dibanding kelompok kontrol. Setelah kelompok eksperimen diberikan perlakukan selama satu kali pertemuan, maka terdapat perubahan perbedaan yang signifikan antara skor kesiapan belajar matematika siswa pada kelompok eksperimen dan kelompok kontrol, perbedaan tersebut ditunjukkan dengan perbedaan rata-rata antara kedua kelompok sebesar 1,080 dengan $t=0,577$ dan sig. $(0,565)$. Kelompok eksperimen mengalami peningkatan skor kesiapan belajar matematika sedangkan kelompok kontrol yang menggunakan metode pembelajaran tradisional, mengalami sedikit penurunan skor. 


\section{PEMBAHASAN}

Metode pembelajaran kooperatif yang diterapkan kepada subjek selama perlakuan sesuai dengan prinsip belajar, yaitu dalam belajar setiap siswa harus berpartisipasi aktif, harus dapat menimbulkan reinforcement dan motivasi yang kuat pada siswa untuk mencapai tujuan instruksi pembelajaran, perlu lingkungan yang menantang dimana anak dapat mengembangkan kemampuannya bereksplorasi dan belajar dengan efektif, dan perlu ada interaksi siswa dengan lingkungannya (Slameto, 2013).

Proses pembelajaran yang bertujuan untuk meningkatkan partisipasi siswa secara aktif, efektif dan interaktif membutuhkan kondisi hubungan antar siswa yang baik. Metode pembelajaran kooperatif ini dapat merekatkan hubungan atau interaksi antar siswa maupun dengan guru sehingga proses pembelajaran berjalan dengan efektif, siswa dapat berpartisipasi secara aktif dan terjadinya interaksi siswa dengan lingkungannya dikelas secara baik. Penelitian Ryzin dan Roshet (2018) menunjukkan bahwa pembelajaran kooperatif dapat meningkatkan keterkaitan antar siswa dan mampu mengurangi tekanan pada siswa yang merasa terpinggirkan. Penelitian Altun (2015) menemukan bahwa pembelajaran kooperatif melibatkan bekerja sama untuk sebuah tujuan bersama dan menciptakan lingkungan belajar-mengajar yang kaya interaksi antar siswa.

Hasil observasi selama proses penerapan metode pembelajaran berlangsung menunjukkan bahwa setiap sesi pada metode pembelajaran kooperatif sudah terpenuhi namun belum maksimal, hal ini dapat dilihat ketika proses diskusi berlangsung dimana tatap muka, komunikasi antar anggota, saling ketergantungan positif, tanggung jawab individu dan evaluasi kelompok sudah terpenuhi namun ada beberapa siswa yang terlihat kurang aktif walaupun sudah berada dalam kelompok. Hal tersebut biasa terjadi karena setiap siswa mempunyai model atau gaya respon yang berbeda-beda. Mann (Nasution, 2017) menyebutkan bahwa ada 8 macam model atau gaya siswa merespon yakni: siswa penurut dimana siswa sangat bergantung kepada guru untuk membantu mereka dalam pelajaran, siswa yang patah semangat yakni tidak puas dengan dirinya, siswa yang dapat berdiri sendiri yakni mereka percaya akan dirinya sehingga merasa dirinya aman, siswa pahlawan dimana mereka senantiasa terlibat dalam setiap "pemberontakan" dalam sekolah, siswa "penembak tersembunyi" seperti siswa pahlawan mereka ini mempunyai jiwa pemberontak akan tetapi perlawanan mereka tidak diperlihatkan dengan nyata, siswa penarik perhatian yakni mereka sangat berorientasi pada hubungan sosial, dan siswa pendiam dimana mereka merasa dirinya tak mampu dan tidak berkuasa.

Dengan penerapan metode pembelajaran kooperatif maka dapat memberikan sebuah media interaksi siswa yang beragam karakter sehingga tidak terlihat dengan jelas perbedaan tersebut. Ryzin dan Roshet (2018) telah menemukan bahwa pembelajaran kooperatif secara signifikan dapat mengurangi perundungan, penindasan, dan tekanan 
yang dirasakan bagi siswa yang terpinggirkan dan mengurangi masalah emosional serta meningkatkan keterkaitan untuk semua siswa.

Kesimpulan bahwa Pembelajaran Kooperatif dapat meningkatkan kesiapan belajar matematika siswa selaras dengan penelitian Parveen, Yousuf, dan Mustafa (2016), bahwa metode pembelajaran kooperatif lebih baik daripada metode pembelajaran konvensional. Altun (2015) mengungkapkan bahwa metode pembelajaran kooperatif memiliki efek yang menguntungkan pada pembelajaran.

Penelitian ini telah membuktikan secara empiris bahwa metode pembelajaran kooperatif mampu meningkatkan kesiapan siswa dalam belajar matematika. Pelajaran yang rumit dan sulit ketika dipelajari secara bersama sama dan ada proses saling ketergantungan secara positif, komunikasi yang saling mendukung dan peran aktif semua. Hasil penelitian ini semoga menambah wawasan di bidang psikologi pendidikan umumnya dan dibidang pelatihan khususnya.

\section{DAFTAR PUSTAKA}

Altun, S. (2015). The Effect of Cooperative Learning on Students' Achievement and Views on the Science and Technology Course. Yildiz Technical University, Faculty of Education, sertelaltun@gmail.com

Fajri, N., Yoesoef, A., \& Nur, M., (2016). Pengaruh Model Pembelajaran Koooperatif Tipe Talking Stick Dengan Strategi Joyful Learning Terhadap Prestasi Belajar Siswa Pada Mata Pelajaran IPS Kelas VII MTsN Meuraxa Banda Aceh. Universitas Syiah Kuala: Program Studi Pendidikan seajarah FKIP

Fitriana, E. (2013). Hubungan antara Kesiapan Belajar Dengan Hasil Belajar Matematika Warga Belajar Kelas XI Kelompok Belajar Paket C SKB Bondowoso Semester Genap Tahun Pelajaran 2012-2013. Skripsi. Universitas Jember

Gewati, M. (2018). Kemampuan Matematika Siswa Indonesia Memprihatinkan, Solusinya?. Diakses dari https://edukasi.kompas.com/ pada tanggal 20 April 2018

Indiyani, N E. Listiara, A. (2006). Efektivitas Metode Pembelajaran Kooperatif Untuk Menurunkan Kecemasan Siswa Dalam Menghadapi Pelajaran Matematika.

Kamus besar Bahasa Indonesia. (2008). Jakarta: Gramedia Pustaka Utama

Lie, A. (1999). Metode Pembelajaran Kooperatif. Surabaya: Universitas Kristen Surabaya.

Marliani, R. ( 2016). Psikologi Eksperimen. Bandung: CV Pustaka Setia

Mulyani. (2013). Hubungan Kesiapan Belajar Siswa dengan Prestasi Belajar. Padang:universitas Negri Padang fakultas Ilmu Pendidikan 
Nasution, S. (2017). Berbagai Pendekatan Dalam Proses Belajar dan Mengajar. Jakarta: Bumi Aksara

Parveen, Q.,Yousuf, M. I., and Mustafa, S. (2018). An Experimental Study on the Effect of Cooperative Learning on Students Academic Achievement at Primary Level. Division of Continuing Education, and Department of Mathematics, PMAS-Arid Arid Agriculture University, Rawalpindi, Pakistan.

Ryzin, M, J, V., Roseth, C, J. (2018). Cooperative Learning in Middle School: A Mean to Improve Peer Relations and Reduce Victimization, Bullying, and Related Outcomes. Journal of Educational Psychology. Oregon Research Institute, Eugene, Oregon and Michigan State University. American Psychological Association

Saputri, D, L. Budiyono. (2016). Hubungan Pola Asuh Orang Tua, Minat Belajar dan Kesiapan Belajar Terhadap Prestasi Belajar Matematika. Universitas Muhammadiyah. Program Studi Pendidikan Matematika

Slameto, D. 2013. Belajar dan Faktor-Faktor yang mempengaruhinya. Jakarta: Rineka Cipta.

Suwangsih, E., Putri, H. E., Widodo, S., \& Ikhwanudin, T. (2018). Pengembangan Model Pembelajaran Konsep Bilangan Bagi Anak Dengan Mathematics Learning Disability di Sekolah Dasar Inklusi. IndoMath: Indonesia Mathematics Education, 1(1), 1-18 